\title{
In memory of Dicle Koğacioğlu (1972-2009)
}

Dicle Koğacıoğlu, a sociologist at Sabancı University's Cultural Studies program, a feminist activist, and a good friend and colleague of many of the members the Editorial Board of New Perspectives on Turkey, took her own life on 5 October 2009. Dicle was an author and reader of this journal, and we had been looking forward to her further contributions to and sharp interventions in the social sciences in Turkey at the time of her unexpected death. We dedicate this issue of New Perspectives on Turkey to her memory, in the hope of keeping alive the spirit which she brought to sociological inquiry.

Dicle received her BA degree in sociology from Boğaziçi University in 1994. She continued to study sociology at the PhD level, receiving her degree from the State University of New York at Stony Brook in 2003. She concentrated on the sociology of law during her doctoral studies and focused on the same area during a post-doctoral fellowship at Columbia University. Upon her return to Turkey, she took up a position as assistant professor at Sabancı University's Cultural Studies program in 2005, while also pursuing activism in the Amargi feminist collective.

Her dissertation was an ethnographic study on the interactions between citizens and the legal authorities in the courthouse. ${ }^{1}$ In an article based on her dissertation and published in this journal, as well as in a book chapter, she showed how the unequal relations of power in Turkey were reproduced in the courtroom along the axes of class ${ }^{2}$ and gender. ${ }^{3} \mathrm{Nev}$ -

1 Dicle Kogacıoglu, "Law in Context: Citizenship and Reproduction of Inequality in an Istanbul Courthouse" (Unpublished PhD Dissertation, State University of New York at Stony Brook, 2003).

2 "Conduct, Meaning and Inequality in an Istanbul Courthouse," New Perspectives on Turkey, no. 39 (2008).

3 "Citizenship in Context: Rethinking Women's Relationships to the Law in Turkey," in Citizenship and the Nation State in Greece and Turkey, eds. Faruk Birtek and Thalia Dragonas (London: Routledge, 2005). 
ertheless, poor citizens who were not well-versed in the hardly accessible procedures and language of the courtroom also strategized within this system, through what might be called "making do" (idare etmek). As one of the few social scientists in Turkey who ventured into the relationship between law, competing notions of justice, and the social, Dicle pursued a mode of inquiry along these lines in other publications as well. In an article in which she compared the Turkish Constitutional Court's rulings in the 1990s on the closing-down of two political parties (an Islamist party and a pro-Kurdish party), she argued that the high court drew an arbitrary boundary between the political and cultural domains and then claimed to protect this boundary through its decisions. ${ }^{4}$ She said: "The Court operates with the understanding that once this boundary is transgressed, what may be harmless when an issue is cultural-such as the use of the headscarf or of the Kurdish language - may turn into a political symbol threatening the basis of the united, democratic, and progressive nation-state." 5

Dicle carried her feminist activism into her scholarship through her contributions to the debate on honor crimes in Turkey in two articles and several conference presentations. While international organizations (IOs) and several non-governmental organizations (NGOs) in Turkey were concerned about a perceived increase in honor killings and how to prevent them, Dicle intervened in this debate by questioning the representation of honor crimes in the media, in NGO work, and in police reports. Particularly, she drove attention to the fact that women's bodies are always disciplined through codes of honor; as such, honor crimes are only the tip of the iceberg in a series of patriarchal practices. ${ }^{6} \mathrm{Nev}$ ertheless, recent discourses decouple honor crimes from patriarchy and label it as a consequence of "traditions" and "culture," which are described as something immutable. Dicle especially pointed out that the public discourse on tradition creates an "other," namely the Kurds, who are supposed to be living according to traditions. In the context of neoliberalism in Turkey, the state's role has been supplanted by new actors (such as NGOs and IOs) and new ways of intervening in honor crimes. Dicle argued that, when honor crimes are coded as "tradition," it becomes an object of technical intervention (with associated forms of knowledge production by NGOs and IOs) that removes the need to talk about politics,

4 Dicle Kogacioglu, "Progress, Unity, and Democracy: Dissolving Political Parties in Turkey," Law and Society 38 , no. 3 (2004).

5 Ibid.: 433.

6 Dicle Koğacıoğlu, "Gelenek Söylemleri ve Iktidarın Doğallaşması: Namus Cinayetleri Orneği," Kültür ve Siyasette Feminist Yaklaşımlar, June 2007 (available from http://www. feministyaklasimlar.org/index. php?act=in). (Also published in "Gelenek Söylemleri ve Iktidarın Doğallaşması: Namus Cinayetleri Ornełi," Cogito Feminizm Ozel Dosyası, no. $5^{8}$ (2009).) 
forced migration, the Kurdish armed struggle, and so on. According to her, this move makes invisible the relations of power between those who do the intervening and the population groups in whose lives they intervene. In another article, Dicle argued that honor crimes, instead of being treated as emanating from culture, should be analyzed as the effects of certain institutional structures. ${ }^{7}$ Pursuing the same line of inquiry, Dicle also problematized Turkish newspaper articles and police reports on honor crimes in recent years, emphasizing how these accounts attributed honor killings to Kurdishness or to the East of Turkey. ${ }^{8}$ Particularly, the category of honor crimes was constructed in the process of knowledge production, such as in an annual report issued by the police department, seemingly an unbiased document. ${ }^{9}$ Several articles that came out of presentations at the Hrant Dink Memorial Workshop, where she also presented her work, are published in this issue of New Perspectives on Turkey, and it is painful to think that, had she not left us, she could have contributed to this issue with her paper.

Dicle questioned the relationship between social power and bureaucratic forms of authority (such as the judicial system, law enforcement, or the military) in her collaborative work with her colleagues as well. She co-organized a workshop on "Bureaucracy' and Social Power"; the call for participation invited paper presenters to rethink bureaucracy as a power scheme in which structures, practices, techniques, affects, dispositions and cultural memory intersected and interacted with each other. ${ }^{10}$ Through forums such as this workshop and her role as a mentor for MA students in the Cultural Studies program at Sabanci, she also actively supported young scholars in their research.

Dicle left unfinished a highly original research agenda on the links between power, justice, and gender, class and ethnic inequality. Her critical mind, her good humor, friendship and mentorship will be very much missed by her colleagues, friends and students in the social science community in Turkey and abroad.

\section{Editorial Board, New Perspectives on Turkey}

7 Dicle Kogacioglu, "The Tradition Effect: Framing Honor Crimes in Turkey," differences: A Journal of Feminist Cultural Studies 15, no. 2 (2004).

8 Dicle Koğacıoğlu, "Two-Timing Recognition? Identity and Temporality in Discourses on Honor Crimes" (paper presented at the Conference on Gender Studies in Turkey, Koç University, Istanbul, 30 November 2008).

9 "Namus Cinayeti Söylemlerinde Bilgi ve Siyasi Cemaat" (paper presented at the Hrant Dink Memorial Workshop, Sabancı University, Istanbul, 22 May 2009).

10 Dicle Kogacıoglu and Meltem Ahıska (co-organizers), 'Bürokrasi' ve Toplumsal Iktidara Iliskin Yeni Sorular (Sabancı University Center in Karaköy, İstanbul, 4-5 July 2009). 


\section{References}

Kogacioglu, Dicle. "Progress, Unity, and Democracy: Dissolving Political Parties in Turkey." Law and Society 38, no. 3 (2004): 433-61.

- "The Tradition Effect: Framing Honor Crimes in Turkey." differences: A Journal of Feminist Cultural Studies 15, no. 2 (2004): 118-51.

Koğacıoglu, Dicle. "Citizenship in Context: Rethinking Women's Relationships to the Law in Turkey." In Citizenship and the Nation State in Greece and Turkey, edited by Faruk Birtek and Thalia Dragonas, 144-61. London: Routledge, 2005.

- "Conduct, Meaning and Inequality in an Istanbul Courthouse." New Perspectives on Turkey, no. 39 (2008): 97-127.

—. "Celenek Söylemleri ve Iktidarın Doğallaşması: Namus Cinayetleri Örneği." Kültürve Siyasette Feminist Yaklaşımlar, June 2007. (available from http://www.feministyaklasimlar.org/index.php?act=in)

—. "Gelenek Söylemleri ve Iktidarın Doğallaşması: Namus Cinayetleri Orneği." Cogito Feminizm Ozel Dosyası, no. 58 (2009): 350-84.

-. "Law in Context: Citizenship and Reproduction of Inequality in an Istanbul Courthouse." Unpublished PhD Dissertation, State University of New York at Stony Brook, 2003.

—- "Namus Cinayeti Söylemlerinde Bilgi ve Siyasi Cemaat." Paper presented at the Hrant Dink Memorial Workshop, Sabanci University, Istanbul, 22 May 2009.

-. "Two-Timing Recognition? Identity and Temporality in Discourses on Honor Crimes." Paper presented at the Conference on Cender Studies in Turkey, Koç University, Istanbul, 30 November 2008.

Koğacıoğlu, Dicle, and Meltem Ahıska (co-organizers). 'Bürokrasi' ve Toplumsal Iktidara ilişkin Yeni Sorular. Sabancı University Center in Karaköy, Istanbul, 4-5 July 2009. 